\title{
PERANCANGAN SISTEM INFORMASI KONTROL PRODUKSI SEPATU (STUDI KASUS: PT. ASIA DWIMITRA INDUSTRI TANGERANG)
}

\author{
Samsoni \\ Teknik Informatika, Fakultas Teknik, Universitas Pamulang \\ e-mail: samsoni_smart@yahoo.com
}

\begin{abstract}
ABSTRAK
PT. Asia Dwimitra Industri adalah badan usaha yang berbentuk perseroan terbatas, didirikan di Tangerang pada tahun 2008. Perusahaan ini memproduksi sepatu olahraga dengan merek NIKE. PT. Asia Dwimitra Industri memiliki visi, menjadi Manufacturing Berkelanjutan, Mitra Terpercaya, dan Perusahaan Menguntungkan.Salah satu cara untuk mencapai visi tersebut maka PT. Asia Dwimitra Industri sangat mengutamakan pemenuhan target produksi. Sementara masalah yang dihadapi perusahaan adalah dalam usaha untuk memenuhi ketepatan waktu kirim order, hal ini disebabkan karena sistem perencanaan dan pengendalian produksi yang kurang baik sehingga mengakibatkan keterlambatan pengiriman komponen bahan baku yang dapat menghambat jalannya produksi ataupun keterlambatan produksi yang disebabkan oleh kesalahan dalam memprediksi lama waktu proses produksi pada saat penjadwalan. Sehingga perusahaan mengalami kesulitan dalam mengendalikan produksi sepatu yang lebih efisien. Adapun tahapan-tahapan penelitian yang dilakukan adalah pengumpulan data, pembuatan OPC, menghitung waktu standartmembuat struktur produk. Dari hasil perhitungan tersebut di ketahui kapan dan berapa jumlah bahan baku dan komponen yang dibutuhkan. Sistem Informasi ini menggunakan bahasa pemrograman web seperti PHP, CSS, HTML dan untuk database menggunakan database MySQL serta beberapa tools pendukung lainnya seperti sublime, notepad++. Xampp untuk dapat menjalankan aplikasi ini pada lokal server. Untuk perancangan yang digunakan adalah menggunakan UML yaitu penggunaan usecase diagram, activity diagram, sequence diagram dan class diagram.
\end{abstract}

Kata Kunci: Produksi, UML, MySQL, Sistem, Kontrol.

\section{PENDAHULUAN}

Dalam dunia usaha untuk dapat bertahan dalam persaingan yang datangnya bukan hanya dari perusahaan dalam negeri melainkan juga dari luar negeri maka perusahaan makin dituntut mampu mengusahakan suatu produk yang memiliki daya saing yang kuat untuk dapat bertahan dan dapat menguasai pasar. Dan diramalkan hanya produk yang memiliki kwalitas dan pelayanan yang baik dengan biaya yang lebih rendah akan menguasai pasar.

Seiring dengan perkembangan tersebut, pihak manajemen dari PT. ASIADWIMITRA INDUSTRI perusahaan yang bergerak dalam bidang pembuatan sepatu olahraga yang mayoritas produknya diekspor, merasa perlu mengusahakan peningkatan pelayanan terhadap konsumen terutama dalam hal pemenuhan target pengiriman barang dengan tepat waktu, tentu dengan tidak melupakan kwalitas hasil produksi dan biaya yang seminimal mungkin.

Dalam setiap penerimaan sebuah order maka akan diberikan batas waktu untuk pengiriman yang telah disetujui oleh kedua belah pihak. Dalam usaha memenuhi target produksi guna mengejar batas waktu pengiriman. Hal ini penting demi reputasi dan kepercayaan konsumen terhadap tingkat keprofesionalan kerja dari perusahaan. Berdasarkan uraian diatas, maka penulis tertarik untuk melakukan penelitian dengan judul: "PERANCANGAN SISTEM INFORMASI KONTROL PRODUKSI SEPATU (STUDI KASUS: PT. ASIA DWIMITRA INDUSTRI TANGERANG )".

Mengingat ruang lingkup sistem kontrol produksi cukup luas, maka dalam penelitian ini, sistem yang dibuat memiliki batasan-batasan sebagai berikut:

a. Sistem dapat merencanakan produksi sepatu mulai dari material hingga hasil produk.

b. Sistem dapat memberikan informasi kontrol produksi sudah berapa jumlah sepatu yang dapat dibuat dalam waktu yang di tentukan.

c. Bahasa pemrograman yang digunakan dengan PHP dan menggunakan 
Framework CodeIgniter dengan
Database MySQL.

Berdasarkan latar belakang di atas, maka penulis merumuskan permasalahan sebagai berikut:

a. Bagaimana dapat menyusun atau melakukan pengendalian produksi sepatu dengan cepat?

b. Bagaimana merancang sistem informasi kontrol produksi sepatu yang baik untuk dapat membuat suatu sistem informasi yang membantu melakukan kontrol produksi sepatu?

Tujuan dari penelitian ini adalah:

a. Untuk merancang suatu prosedur perencanaan dan penjadwalan produksi dari setiap departemen produksi dengan harapan proses produksi dapat berjalan lebih lancar dan lebih efisien.

b. Merencanakan kebutuhan material dan menentukan saat yang tepat untuk melakukan order supaya tersedianya bahan baku lebih terjamin.

\section{METODE PENELITIAN}

Berikut ini adalah prosedur sistem berjalan yang ada pada PT. ASIA DWIMITRA INDUSTRI TANGERANG. Proses yang dilakukan pada sistem berjalan dimulai dari bagian produksi memilih material yang ada lalu bagian produksi menerima permintaan untuk segera dilakukan proses produksi, kemudian melakukan input permintaan tersebut dan melakukan proses produksi. Kemudian bagian kontrol menerima hasil dari produksi dan melakukan pengecekan, jika tidak maka akan masuk lagi pada proses produksi dan jika ya maka proses kontrak pada proses produksi yang dilanjutkan. Kemudian bagian finishing menerima hasil dari produksi dan kemudian melakukan finishing serta melakukan input data finishing dan menjadi sebuah laporan yang diterima oleh bagian produk dari bagian finishing dan selesai.

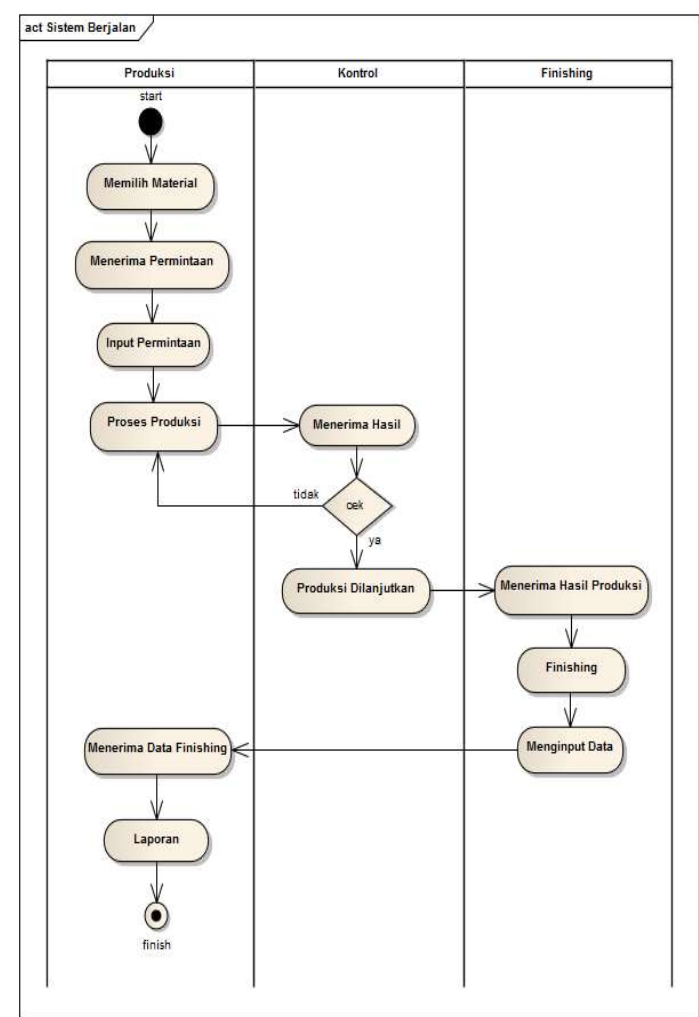

Gambar 3.1 Flowchat Sistem Berjalan

\section{PEMBAHASAN}

Berdasarkan permasalahan yang ada di PT. Asia Dwimitra Industri Tangerang, maka sistem yang diusulkan adalah:

1. Sistem Informasi Kontrol Sepatu yang di kelola oleh admin dengan terkomputerisasi pada sistem yang dapat memberikan informasi kontrol sepatu dari produksi hingga finishing secara cepat dan tepat.

2. Rancangan Aplikasi Diagram UML (Unified Modeling Language) yang menggambarkan model dalam aplikasi ini terdiri dari Use Case Diagram, Activity Diagram, Sequence Diagram, Class Diagram, ERD Diagram dan LRS Diagram. 


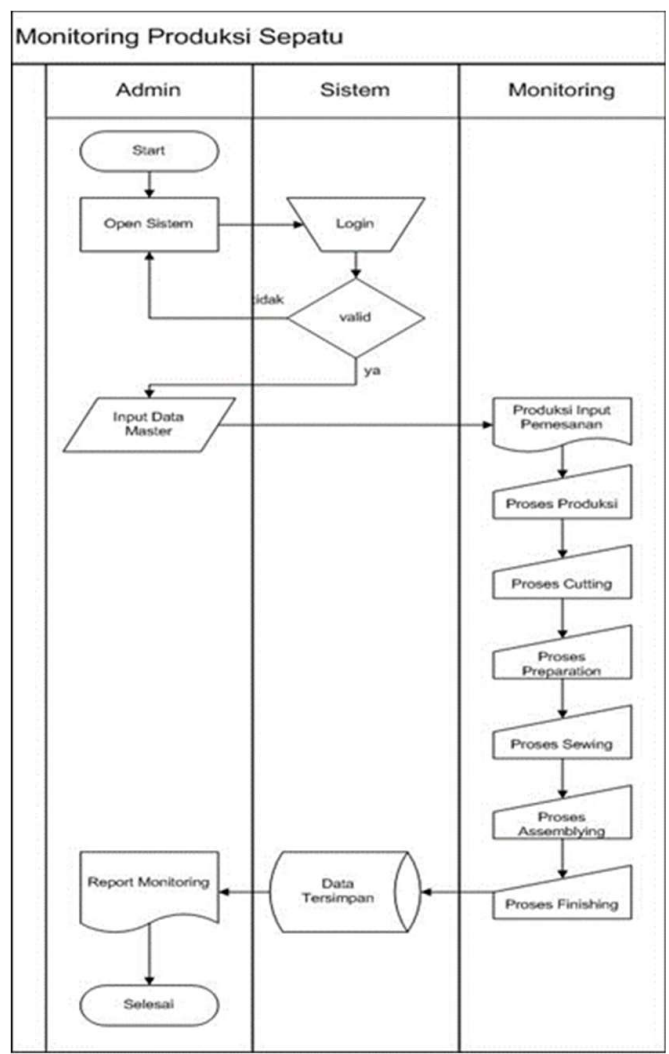

Gambar 3.2 Flowchart Sistem Usulan

\section{Use case Diagram Sistem Usulan Produksi}

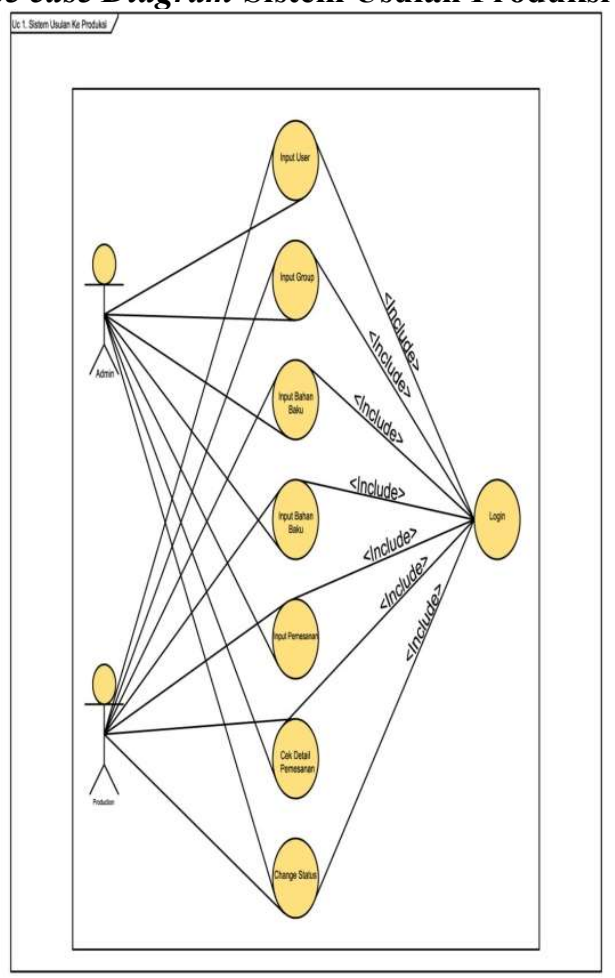

Gambar 3.3 Use case

Diagram Sistem Usulan Produksi

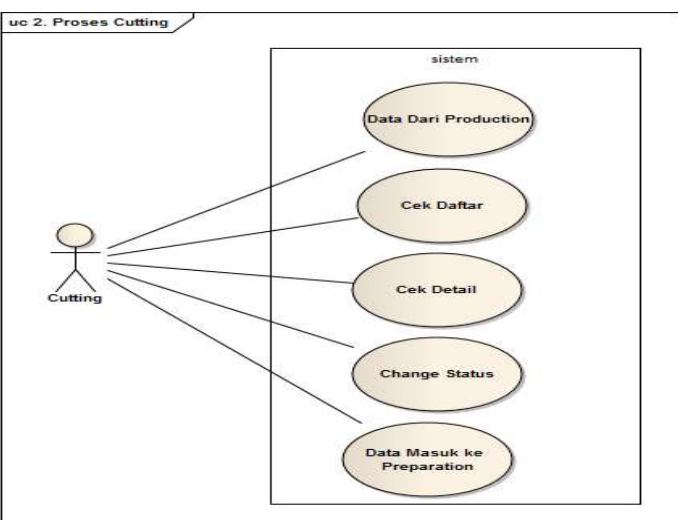

Gambar 3.4 Usecase DiagramProses Cutting

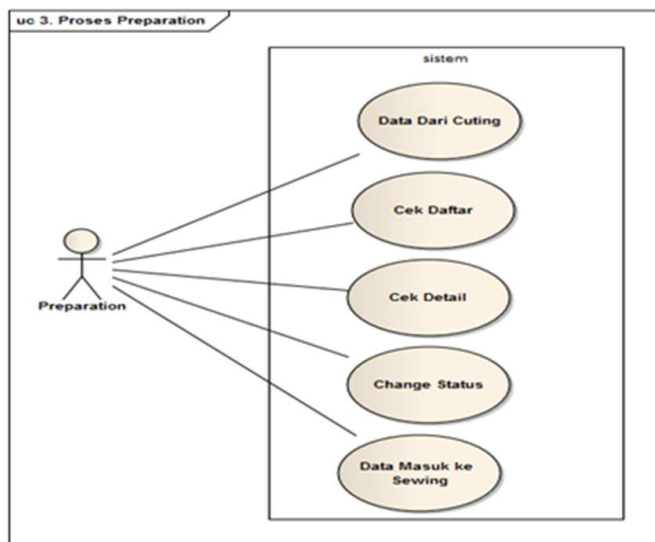

Gambar 3.5 Usecase Diagram Preparation

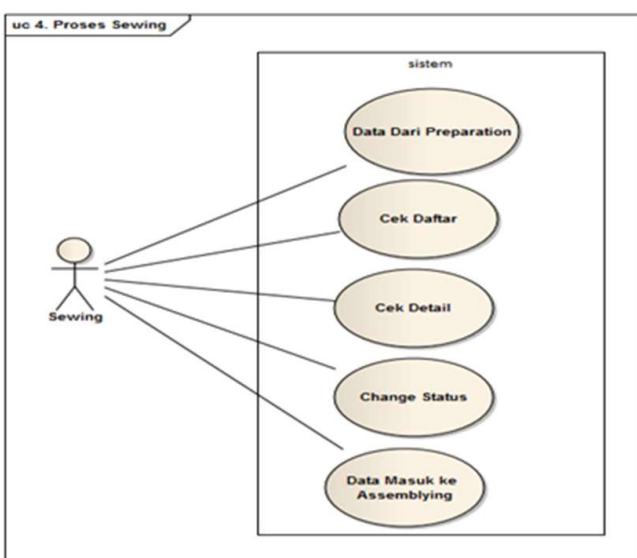

Gambar 3.6 Usecase Diagram Sewing

\section{Class Diagram}




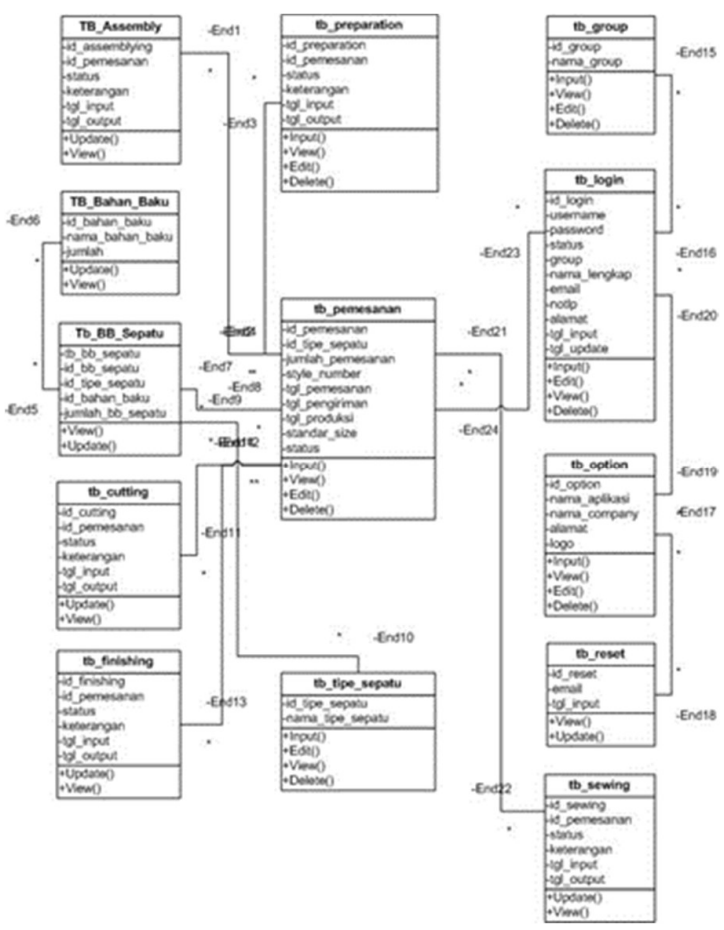

Activity Diagram Sistem Usulan Activity Diagram Sistem Usulan Produksi

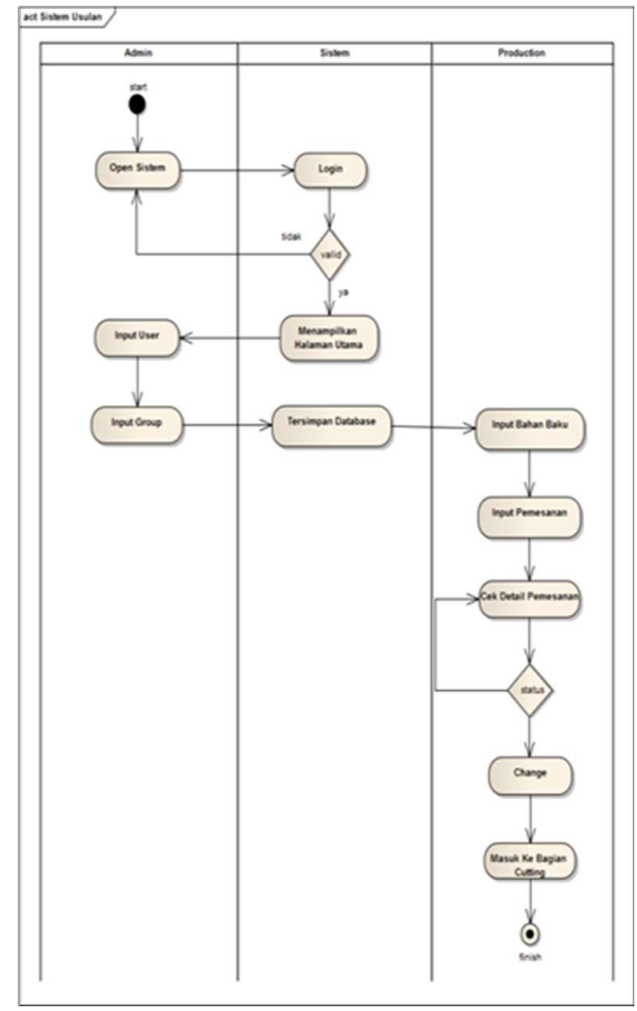

Gambar 3.10 Actvity Diagram Sistem Usulan produksi

\section{Activity Diagram Proses Cutting}

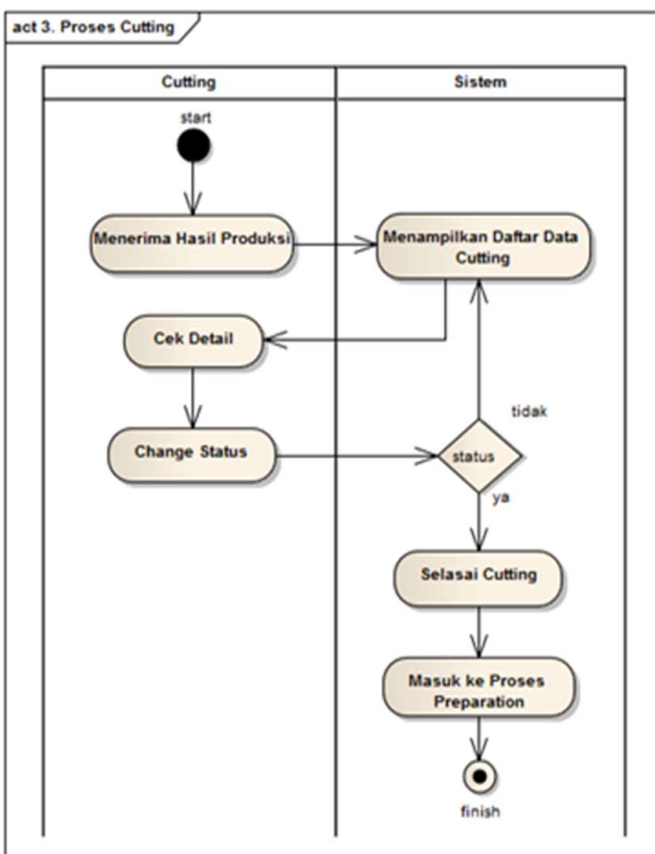

Gambar 3.10 Actvity Diagram Proses Cutting

Implementasi merupakan tahap menerjemahkan perancangan berdasarkan hasil analisis. Tujuan implementasi adalah untuk mengkonfirmasikan modul program perancangan pada para pelaku sistem sehingga user dapat memberi masukan kepada pengembang sistem.

\section{Lingkungan Perangkat Lunak}

Adapun perangkat lunak yang digunakan untuk mengimplementasikan perangkat lunak ini adalah sebagai berikut:

Tabel 4.1 Perangkat Lunak

\begin{tabular}{|l|l|l|}
\hline No. & \multicolumn{1}{|c|}{ Perangkat Lunak } & \multicolumn{1}{|c|}{ Implementasi } \\
\hline 1. & $\begin{array}{l}\text { Microsoft Windows } 8 \\
\text { Ultimate 32-bit }\end{array}$ & Sistem Operasi \\
\hline 2. & Bahasa Pemrograman & PHP 5, SQL \\
\hline 3. & Software Aplikasi & $\begin{array}{l}\text { Notepad++, } \\
\text { XAMPP, } \\
\text { MySQL }\end{array}$ \\
\hline
\end{tabular}

\section{Spesifikasi Perangkat Keras}

Perangkat keras (hardware) merupakan proses analisis yang lebih menekankan kepada aspek pemanfaatan perangkat keras yang selama ini telah ada.

Adapun spesifikasi perangkat keras komputer yang dipakai adalah sebagai berikut: 
Tabel 4.2 Perangkat Keras Komputer

\begin{tabular}{|l|l|}
\hline No. & \multicolumn{1}{|c|}{ Perangkat Keras } \\
\hline 1. & Proccessor Core i3 2,5 GHz \\
\hline 2. & RAM 6 GB DDR 3 \\
\hline 3. & VGA On Board \\
\hline 4. & DVD-ROM \\
\hline 5. & Harddisk 500 GB \\
\hline 6. & Keyboard dan Mouse \\
\hline 7. & Printer \\
\hline 8. & Monitor LED 17' \\
\hline
\end{tabular}

\section{Implementasi Interface}

Pengertian sistem interface adalah salah satu layanan yang disediakan sistem operasi sebagai sarana interaksi antara pengguna dengan sistem operasi. Antarmuka adalah komponen sistem operasi yang bersentuhan langsung dengan pengguna. Terdapat dua jenis antarmuka, yaitu Command Line Interface (CLI) dan Graphical User Interface (GUI). Berikut ini adalah implementasi setiap interface yang dibuat.

Form Halaman admin merupakan sentral dari semua halaman, page ini berisi menu menu utama yang dapat mengakses dan menjadi penghubung antara pengguna / admin dengan sistem. Berikut ini implementasi struktur menu pada halaman utama sistem informasi ini:

Penggunaan Program Menu Admin a. Halaman Login

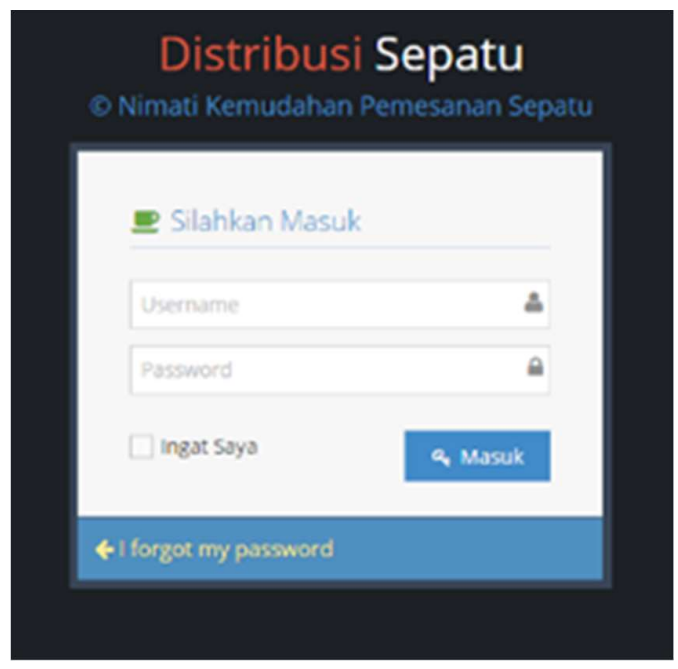

Gambar 4.1 Halaman Login

Tampilan di atas merupakan halaman login untuk masuk pada menu halaman awal.Jika anda ingin melakukan login, maka anda harus memasukan username : admin dan password : admin

\section{b. Menu Halaman Utama}

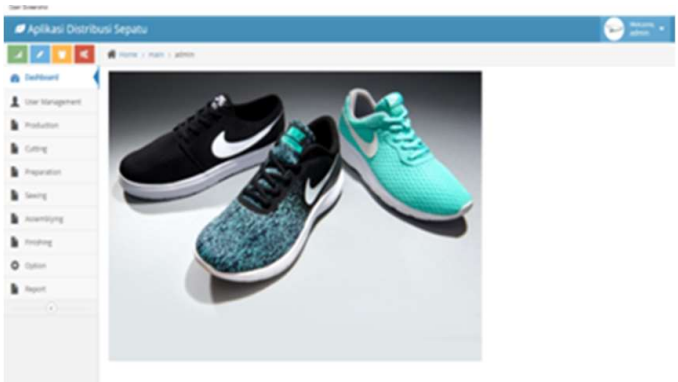

Gambar Menu Halaman Utama

Menu ini befungsi pada saat pengguna melakukan login dengan data yang benar, maka pengguna akan diarahkan pada halaman menu utama ini dan melakukan proses seperti input maser data dan input lainnya.

c. Menu Input Option Profile

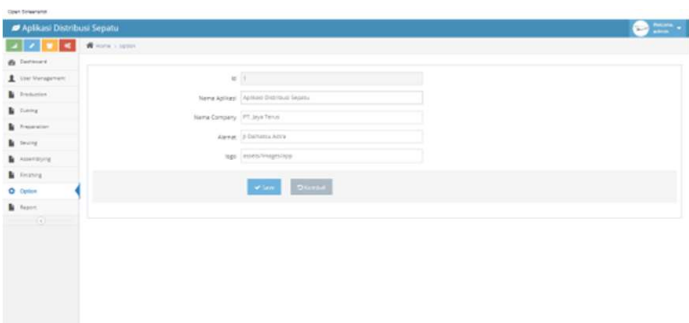

Gambar 4.3 Menu Input Option Profile

d. Menu Daftar Group

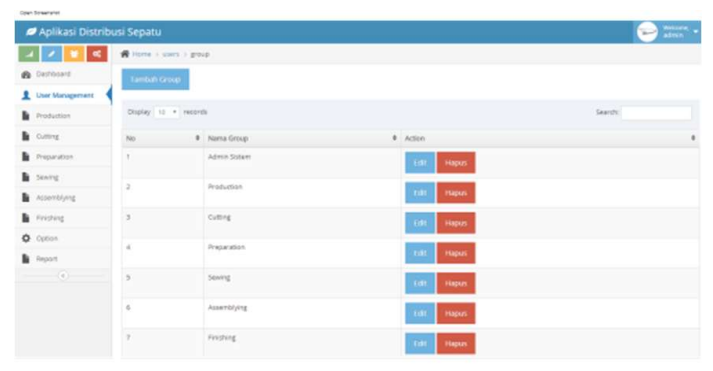

Menu ini berfungsi untuk melihat secara keseluruhan data group dan melakukan edit serta hapus secara permanen data group pada sistem dan melakukan penambahan dengan pilih tombol tambah group.

\section{e. Menu Data User}




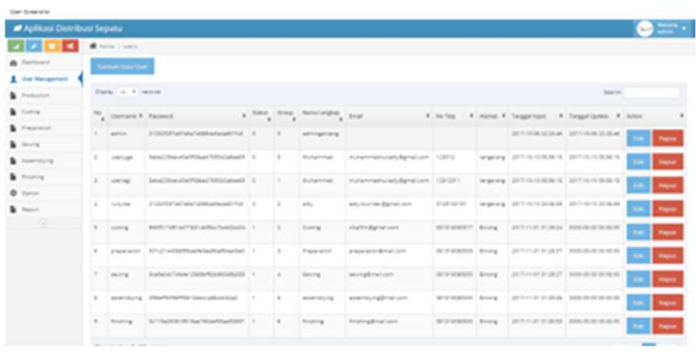

Menu ini berfungsi untuk melakukan review atau melihat data user secara keseluruhan dan dapat melakukan edit data serta hapus data user secara permanen, untuk menambahkan data user klik tombol tambah user.

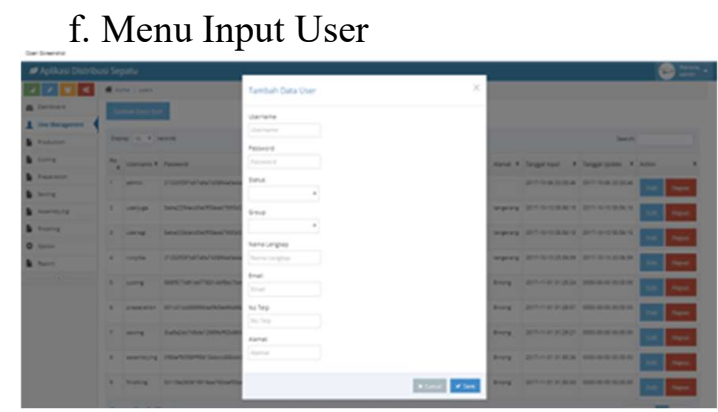

Gambar 4.7 Menu Input User

Menu ini berfungsi untuk melakukan input user baru dengan carai mengisi form tambah data user dan klik tombol save.

\section{KESIMPULAN}

Berdasarkan implementasi dan pengujian pada bab-bab sebelumnya. Maka dapat ditarik suatu kesimpulan dari sistem informasi monitoring kinerja ini, yaitu :

1. Dengan menggunakan sistem monitoring produksi sepatu ini sudah dapat melakukan pengendalian produksi sepatu dengan cepat hanya dengan cara melihat pada menu report yang dapat memberikan informasi pemesanan sepatu sudah smpai proses tahap produksi hingga proses finishing.

2. Perancangan sistem control produksi sepatu ini menggunakan perancangan UML dimana penggunaan use case diagram, activity diagram, sequence diagram digunakan dalam perancangan sistem informasi kontrol produksi sepatu berbasis web dengan baik dan benar.

\section{DAFTAR PUSTAKA}

Sutabri, Tata. 2012. Konsep Dasar Sistem Informasi. Yogyakarta: Andi Offset.

Kadir, Abdul. 2014. Pengenalan Sistem Informasi. Edisi Revisi. Yogyakarta : Andi Offset

Ahyari, Agus, 2011. Management Produksi: Prencanaan sistem produksi,Edisi ke 5, Cetakan -4, Jakarta 